\title{
Performance and Operational Characteristics for a Dual Brayton Space Power System With Common Gas Inventory
}

Paul K. Johnson

Analex Corporation, Brook Park, Ohio

Lee S. Mason

Glenn Research Center, Cleveland, Ohio 


\section{NASA STI Program . . . in Profile}

Since its founding, NASA has been dedicated to the advancement of aeronautics and space science. The NASA Scientific and Technical Information (STI) program plays a key part in helping NASA maintain this important role.

The NASA STI Program operates under the auspices of the Agency Chief Information Officer. It collects, organizes, provides for archiving, and disseminates NASA's STI. The NASA STI program provides access to the NASA Aeronautics and Space Database and its public interface, the NASA Technical Reports Server, thus providing one of the largest collections of aeronautical and space science STI in the world. Results are published in both non-NASA channels and by NASA in the NASA STI Report Series, which includes the following report types:

- TECHNICAL PUBLICATION. Reports of completed research or a major significant phase of research that present the results of NASA programs and include extensive data or theoretical analysis. Includes compilations of significant scientific and technical data and information deemed to be of continuing reference value. NASA counterpart of peer-reviewed formal professional papers but has less stringent limitations on manuscript length and extent of graphic presentations.

- TECHNICAL MEMORANDUM. Scientific and technical findings that are preliminary or of specialized interest, e.g., quick release reports, working papers, and bibliographies that contain minimal annotation. Does not contain extensive analysis.

- CONTRACTOR REPORT. Scientific and technical findings by NASA-sponsored contractors and grantees.
- CONFERENCE PUBLICATION. Collected papers from scientific and technical conferences, symposia, seminars, or other meetings sponsored or cosponsored by NASA.

- SPECIAL PUBLICATION. Scientific, technical, or historical information from NASA programs, projects, and missions, often concerned with subjects having substantial public interest.

- TECHNICAL TRANSLATION. Englishlanguage translations of foreign scientific and technical material pertinent to NASA's mission.

Specialized services also include creating custom thesauri, building customized databases, organizing and publishing research results.

For more information about the NASA STI program, see the following:

- Access the NASA STI program home page at http://www.sti.nasa.gov

- E-mail your question via the Internet to help@sti.nasa.gov

- Fax your question to the NASA STI Help Desk at 301-621-0134

- Telephone the NASA STI Help Desk at 301-621-0390

- Write to:

NASA STI Help Desk

NASA Center for AeroSpace Information 7121 Standard Drive Hanover, MD 21076-1320 
NASA/TM-2006-214393

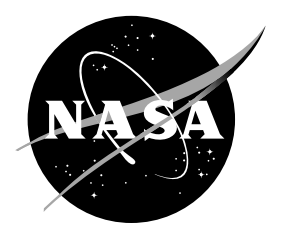

\section{Performance and Operational Characteristics for a Dual Brayton Space Power System With Common Gas Inventory}

Paul K. Johnson

Analex Corporation, Brook Park, Ohio

Lee S. Mason

Glenn Research Center, Cleveland, Ohio

Prepared for the

Fourth International Energy Conversion Engineering Conference and Exhibit (IECEC) sponsored by the American Institute of Aeronautics and Astronautics San Diego, California, June 26-29, 2006

National Aeronautics and

Space Administration

Glenn Research Center

Cleveland, Ohio 44135 


\section{Acknowledgments}

The work in this paper was performed for NASA Headquarters, Prometheus Nuclear Systems Program.

This report contains preliminary findings, subject to revision as analysis proceeds.

Level of Review: This material has been technically reviewed by technical management.

Available from

NASA Center for Aerospace Information 7121 Standard Drive

Hanover, MD 21076-1320
National Technical Information Service 5285 Port Royal Road Springfield, VA 22161 


\title{
Performance and Operational Characteristics for a Dual Brayton Space Power System With Common Gas Inventory
}

\author{
Paul K. Johnson \\ Analex Corporation \\ Brook Park, Ohio 44142 \\ Lee S. Mason \\ National Aeronautics and Space Administration \\ Glenn Research Center \\ Cleveland, Ohio 44135
}

\begin{abstract}
This paper provides an analytical evaluation on the operation and performance of a dual Brayton common gas system. The NASA Glenn Research Center in-house computer program Closed Cycle System Simulation (CCSS) was used to construct a model of two identical $50 \mathrm{kWe}$-class recuperated closed-Brayton-cycle (CBC) power conversion units that share a common gas inventory and single heat source. As operating conditions for each CBC change, the total gas inventory is redistributed between the two units and overall system performance is affected. Several steady-state off-design operating points were analyzed by varying turbine inlet temperature and turboalternator shaft rotational speed to investigate the interaction of the two units.
\end{abstract}

\section{Nomenclature}

$\begin{array}{ll}C I T & \text { compressor inlet temperature } \\ C P R & \text { compressor pressure ratio } \\ D P / P & \text { relative pressure drop } \\ m & \text { mass } \\ P & \text { pressure } \\ R & \text { gas constant } \\ T & \text { temperature } \\ T I T & \text { turbine inlet temperature } \\ T P R & \text { turbine pressure ratio } \\ V & \text { gas volume }\end{array}$

\section{Introduction}

$T_{T}^{H}$

HE closed-Brayton-cycle (CBC) is a candidate thermodynamic cycle for space power conversion applications. The CBC can be integrated with various heat source options including solar heat receivers, radioisotope fuel sources, or fission reactors. Recent NASA studies have investigated CBC-based reactor power systems for the Jupiter Icy Moons Orbiter (JIMO) mission ${ }^{1}$ and for lunar and Mars surface power missions. ${ }^{2,3}$ The reactor heat source could include a separate primary coolant, such as liquid metal, and an intermediate heat exchanger or provide direct heating of the Brayton working fluid via a gas-cooled reactor. The JIMO mission was pursuing the development of a $200 \mathrm{kWe}$ gas-cooled reactor with direct Brayton power conversion. Some of the features of the direct gas-cooled reactor concept that led to its selection for JIMO were reliability, deliverability, cost, and safety. The gas reactor system fulfilled the mission requirements for the envisioned Nuclear Electric Propulsion (NEP) mission with simplified engineering development testing and fewer development hurdles than the other options considered. ${ }^{4}$ For similar reasons, the CBC-based reactor power system is a leading candidate for lunar and Mars surface mission applications. The expected power requirements for surface missions are projected to be in the 25 to $100 \mathrm{kWe}$ range.

Potential CBC designs might consist of multiple power conversion systems to allow for system redundancy. The JIMO mission was considering options that included as few as one Brayton unit and as many as four units with 
variations that utilized shared heat exchangers among the units. ${ }^{5}$ NASA also examined design tradeoffs relating to the number of Brayton units and the expected off-design performance. ${ }^{6}$ There are several architectures to be considered when configuring multiple power conversion systems. One option is for the systems to share a common gas inventory and common heat source, where the working fluid from all the $\mathrm{CBC}$ units combine before entering the heat source and split before entering each CBC unit's respective turbine. Modeling such a power conversion system would provide an understanding of how the gas inventory is distributed among the CBC components during offdesign operation and, ultimately, the impact on overall system performance. A recent Bettis paper explored the performance characteristics of a common-loop multi-Brayton power plant with emphasis on the reactor dynamic response to off-nominal operating conditions. ${ }^{7}$ This paper expands on the Bettis study and examines various operational scenarios including startup, imbalanced speed operation, and single-unit operation with one as standby.

\section{Method}

The approach of this study was to investigate several steady-state, off-design operating points that would provide insight regarding the interaction between two Brayton power conversion units sharing a common gas inventory. Although system transient behavior is of great importance, particularly with respect to a nuclear reactor heat source, one must first gain an appreciation for the impact that one Brayton's operating point has on the other Brayton. Steady-state analysis allows one to observe scenarios that might not otherwise be apparent during transient simulation. Some of the cases analyzed might not represent practical, long-duration operating points, but a wide range of cases is necessary to depict fundamental trends in system performance as operating conditions are varied.

The system can be thought of as two gas flow loops in parallel where each Brayton represents a loop. Therefore, when both Braytons are operating nominally, their exit pressures are equal and their inlet pressures are equal. This holds true even if the shafts are rotating at different speeds. Figure 1 is a block diagram that shows the gas flow from each Brayton combining before entering the heat source and splitting after exiting the heat source. Gas exiting each Brayton is from the recuperator high-pressure exit, and gas entering each Brayton flows to the turbine inlet. This particular setup shows a check valve located at the exit of each Brayton to prevent reverse flow should one of the Braytons become standby (i.e., it is shut off). Without check valves, gas would be forced to flow backwards through the standby loop as the other Brayton continued to operate, because the pressure at the heat source inlet is slightly higher than at the heat source exit. If a steady stream of gas was allowed to flow backwards through a Brayton the shaft would spin in reverse and possibly damage the gas-foil bearings, which are designed for rotation in one direction.

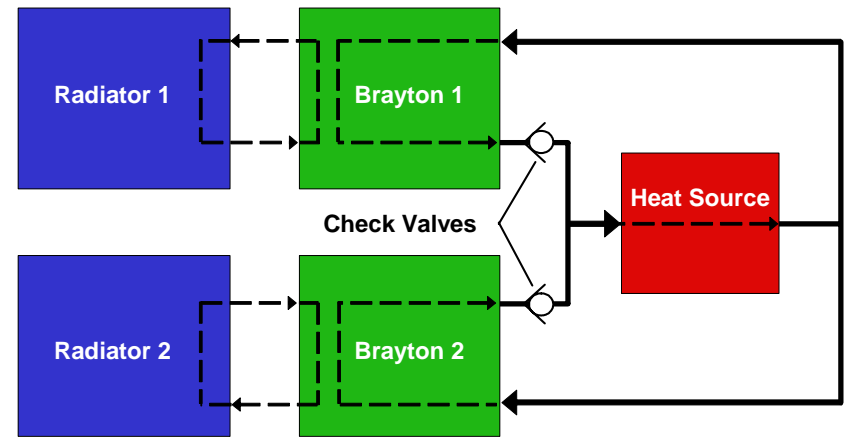

Figure 1. Dual Brayton System Block Diagram.

The distribution of gas throughout the system depends on the gas temperature, pressure, and volume in any given system component. The amount (mass) of gas that resides in a given component is defined by the ideal gas equation.

$$
m=P V / R T
$$

If the Braytons are operating at two different speeds, state-points will adjust accordingly and the gas inventory will naturally redistribute as needed to balance the pressures at the heat source inlet. If one Brayton is standby while the other is operating and check valves are in place as shown in Figure 1, the standby Brayton acts as an accumulator for stagnant gas, and the stagnant gas pressure equilibrates with the heat source exit pressure. Stagnant gas temperature could vary from component to component, but will assume a value bounded by the heat source exit temperature and the environmental far-field sink temperature. After long periods of time the stagnant gas could become uniform throughout the standby Brayton. Regardless of the operating scenario, there is a fixed amount of gas in the system, thus the balance of gas not residing in one Brayton is located in either the other Brayton or the heat source. One would expect the distribution of gas to impact system performance, and the extent of that effect is explored later in the results and discussion section. 


\section{Computer Model}

The Closed Cycle System Simulation (CCSS) is a high-fidelity closed-Brayton-cycle design and analysis tool written in the Numerical Propulsion System Simulation (NPSS) modeling environment. ${ }^{8}$ The source code originated from the NASA Glenn Research Center in-house legacy program Closed Cycle Engine Program (CCEP) and has been used in previous studies. ${ }^{6,9,10,11}$ CCSS models all of the major CBC components (ducts, recuperator, gas cooler, turbine, compressor, alternator, radiator, and heat source) and accounts for details such as shaft bearing and windage losses and bleed flow paths. A representation of a dual Brayton, common gas system was constructed in CCSS and used to simulate steady-state off-design operating points for the purpose of further understanding the general behavior of such a system. The following section describes the individual Brayton components as modeled by CCSS and how they were used to construct the dual Brayton system.

\section{A. Brayton Components}

Gas ducts allow the working fluid to flow from one component to the next. CCSS calculates gas pressure drop and gas mass inventory for each duct. Friction factor is calculated using a Reynolds number correlation for flow through a duct, and inventory is calculated using the ideal gas equation. Duct lengths are input by the user and diameters are sized during design to achieve a specified relative pressure drop (DP/P) across each duct.

The recuperator is a gas-to-gas, counter-flow heat exchanger with offset strip-fins in the core and plain plate fins in the headers. CCSS uses an approach outlined by Kays and London to calculate pressure drops and heat transfer in the core and headers. ${ }^{12}$ Gas mass inventory is calculated for the high- and low-pressure streams using the ideal gas equation. Core width and length are determined during the design to achieve a specified effectiveness and DP/P across the low pressure side of the recuperator. Off-design effectiveness and pressure drops are calculated using the geometries determined from the design run.

The heat source is the most basic Brayton component modeled in CCSS. Ideally, a detailed model would be included to better represent the heat transfer, pressure losses, etc., but the characterization of a nuclear fission reactor is beyond the scope of this study. The heat source instead is represented by a gas volume, fixed relative pressure drop, and user-specified outlet temperature. This simplified heat source is sufficient because this study only investigates steady-state scenarios.

The radiator is a pumped-loop configuration ${ }^{13}$ with sodium-potassium (NaK-78) coolant and an annular linear induction pump (ALIP). CCSS calculates fluid pressure drop and heat transfer using Reynolds number correlations appropriate for liquid metals. At design the coolant duct diameter is sized to achieve a desired pressure drop across the radiator, and panel lengths are sized to reject the appropriate amount of heat. Off-design heat transfer and pressure drops are calculated using the geometries determined from the design run. The gas cooler is nearly identical to the recuperator with the exception that it is a liquid-to-gas heat exchanger without headers, and liquid metal correlations are used for the cold stream calculations.

The compressor, turbine, and alternator rotate on a common shaft supported by gas-foil journal and thrust bearings. The alternator converts shaft power into electric power with an electromagnetic efficiency defined as a function of alternator power. Windage (viscous drag) and bearing losses are estimated as functions of shaft cavity pressure and shaft rotational speed. Generic performance maps are scaled by CCSS to estimate efficiency and pressure ratio for the turbine and compressor as a function of corrected mass flow rate and percent of design corrected speed. The maps were slightly modified to accommodate the low-speed, lowpower operating points anticipated for this study. As is the case with most turbomachinery maps, these maps do not extend to low speeds and low flow rates. Therefore, for model convergence purposes the turbine and compressor maps were extrapolated with the assumption that flow rate is zero at zero speed, and pressure ratio is unity at zero speed and zero flow. Figure 2 is a generic plot of turbine pressure ratio as a function of corrected mass flow rate at lines of constant speed. Dashed lines represent the extrapolated portion of the map.

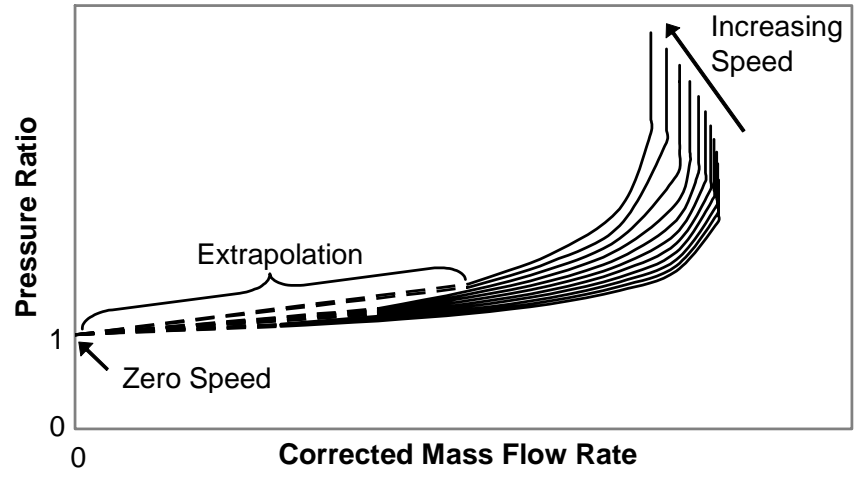

Figure 2. Turbine Performance Map Extrapolated to Zero Flow and Zero Speed. 


\section{B. Dual Brayton System}

Brayton components were arranged in CCSS to construct the dual CBC system of interest. Figure 3 is a schematic of the system design point providing the state point conditions and performance parameters of a dual Brayton system under balanced operation. Each Brayton unit was designed for $50 \mathrm{~kW}$ of electrical power output for a total of $100 \mathrm{~kW}$. Design input parameters such as compressor inlet temperature (CIT) and pressure (400 K and 0.5 $\mathrm{MPa})$, compressor pressure ratio (CPR) (2.0), turbine inlet temperature (TIT) (1150 K), recuperator and gas cooler effectiveness (95 and 97 percent), helium-xenon (He-Xe) working fluid molecular weight $(40 \mathrm{~g} / \mathrm{mol})$, and component DP/P were selected based on previous studies. ${ }^{3,6,9,10}$ The system is configured with 2 percent gas bleed flow for bearing cavity cooling and 5 percent liquid coolant bleed for alternator stator cooling. Radiator NaK mass flow rate was specified to yield the lowest combined gas cooler and radiator mass. All other cycle state points, He-

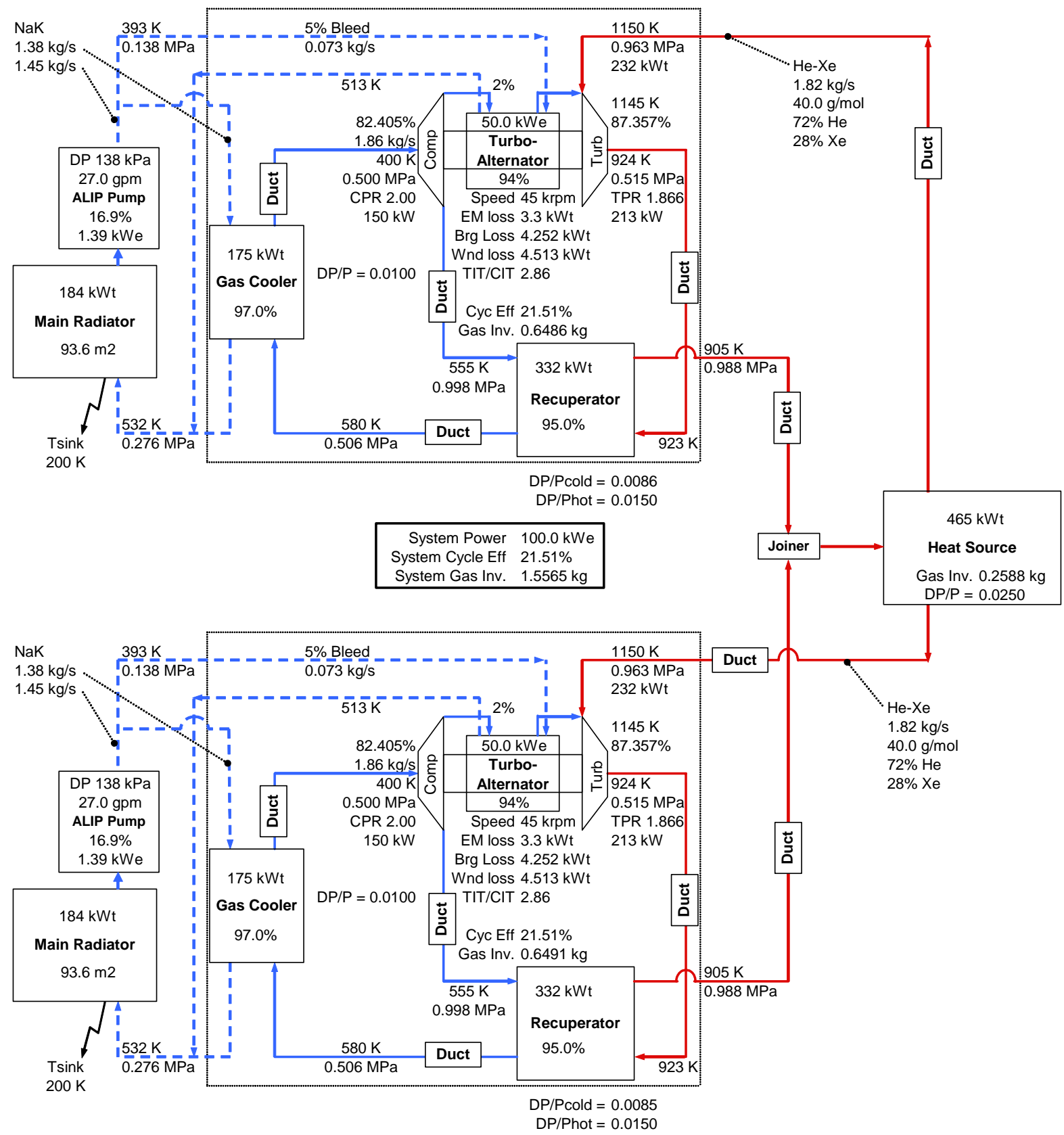

Figure 3. Dual Brayton System Design Point. 
Xe mass flow rate, gas inventory, and system performance are determined by CCSS. Only one design run was required to initialize the system and determine the component design parameters, all subsequent runs were offdesign analysis based on the design point parameters.

\section{Results and Discussion}

The following section presents analytical results of four scenarios. The first three scenarios investigate the effects of (1) imbalance speed operation, (2) single-unit operation with idle unit standby, and (3) motoring power for single- and double-unit startups. The fourth scenario looks at a possible system startup sequence. The variables controlled by the user during these off-design analyses are heat source exit temperature, shaft speed, and stagnant gas temperature when one unit is standby. All other system temperatures, pressures, and inventory distribution adjust accordingly. Radiator NaK mass flow rate remains constant and the potential for coolant freezing is not explored. Freezing can be avoided through flow rate and volume control to prevent NaK coolant temperatures below $262 \mathrm{~K}$.

\section{A. First Scenario: Imbalance Speed Operation}

The first off-design, steady-state scenario investigated the effect of varying the shaft speed of one Brayton (Brayton1) while holding the other Brayton (Brayton2) shaft speed at $45 \mathrm{krpm}$. This scenario could represent a system startup situation where one Brayton is at design speed and the other is slowly increased to design speed. The analysis is also applicable to the graceful shut-down of one Brayton that could occur during an unexpected speed control anomaly or during a potential part-power operating mode.

Figure 4 is a plot of output power for each Brayton as a function of the Brayton1's shaft speed. As shaft speed is reduced from 45 to 15 krpm, Brayton2 power decreases linearly from 50 to $47 \mathrm{~kW}$ and Brayton1 power drops to just 10 $\mathrm{kW}$. The dramatic decrease in Brayton1 power is expected because it is operating at one third of its design speed, but the decrease in Brayton2 power must be explained by the common gas interaction. Figure 5 shows how mass flow rate and gas inventory of each Brayton varies with Brayton1 shaft speed. As Brayton1 shaft speed decreases, Brayton2 mass flow rate drops from 1.8 to 1.6 $\mathrm{kg} / \mathrm{s}$ despite a constant Brayton2 speed of 45 krpm. This occurs because the Brayton1 compressor produces a smaller pressure rise, resulting in a higher cold end pressure in Brayton1 than in Brayton2. The higher gas density in Brayton1 deprives Brayton2 of gas and leaves it with only 40 percent of the shared inventory.

This scenario is a good example of the interdependent nature of a dual Brayton system. Cycle pressures and temperatures change with operating conditions and inventory distribution is governed by the gas density in each component. This is the underlying theme for understanding system behavior for the scenarios in the following sections.

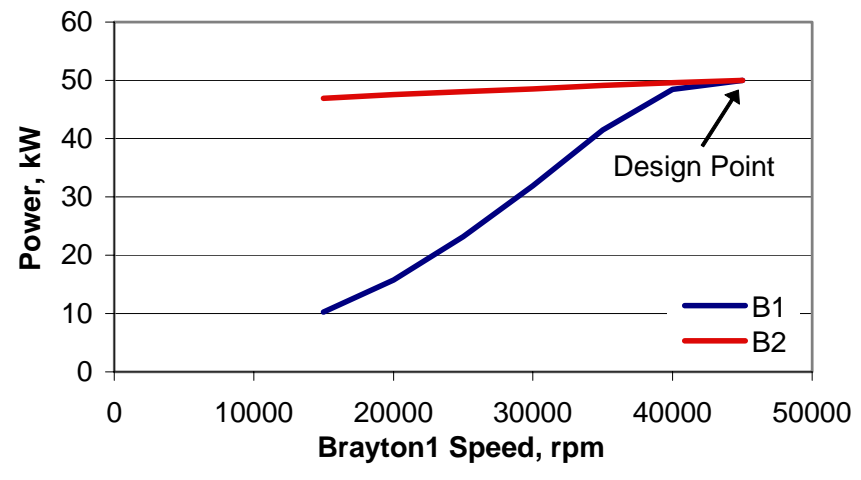

Figure 4. Brayton Output Power as a Function of Brayton1 Shaft Speed.

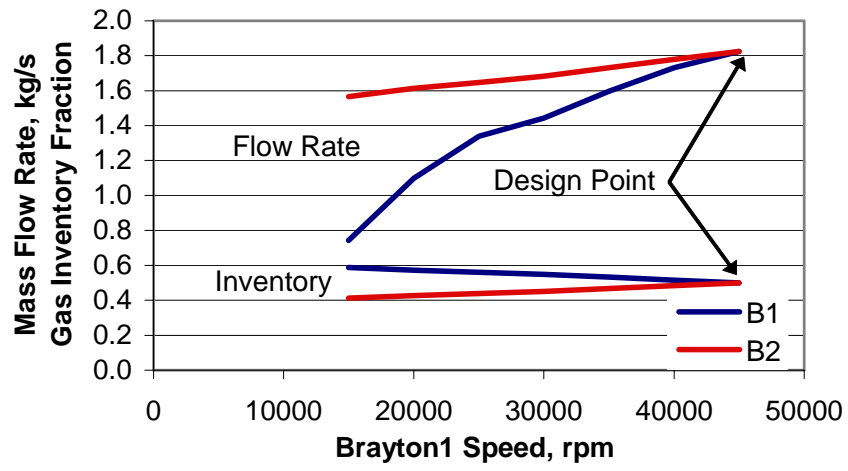

Figure 5. Brayton Gas Inventory and Mass Flow Rate as a Function of Brayton1 Shaft Speed.

\section{B. Second Scenario: Single-Unit Operation with Standby Unit}

The second scenario investigated the effect of gas temperature of a standby Brayton (Brayton1) while the other Brayton (Brayton2) is operated at design speed. A scenario with one Brayton running and the other standby might occur during startup or if one Brayton has to be shut off. A large temperature range (100 to $1000 \mathrm{~K}$ ) was chosen 
because the stagnant gas temperature could vary greatly depending on the situation. For this analysis the gas temperature in Brayton1 is assumed to be uniform throughout (i.e., after reaching steady-state equilibrium).

Figure 6 is a plot of Brayton2 power as a function of Brayton1 stagnant gas temperature, and Figure 7 is a plot of gas inventory division between the two Braytons. For Brayton2 to be able to produce $50 \mathrm{~kW}$ of power a Brayton 1 gas temperature of $1000 \mathrm{~K}$ is required; power output drops to just $18 \mathrm{~kW}$ when the gas temperature is $100 \mathrm{~K}$. At $1000 \mathrm{~K}$ inventory is divided equally between the two Braytons, but at $100 \mathrm{~K}, 90$ percent of the inventory resides in Brayton1. A temperature of $100 \mathrm{~K}$ might be excessively low, but Figures 6 and 7 illustrate that the idle gas temperature has a significant effect on Brayton2's performance; the colder the idle gas gets the more the gas inventory will want to reside in the standby Brayton.

It might be feasible to manage the stagnant gas temperature to alleviate the degradation on performance. For this system, $1000 \mathrm{~K}$ would allow Brayton2 to produce its design power of 50 $\mathrm{kW}$. External heaters could be used to raise the stagnant gas to this temperature, but heater power would have to be considered. A second option is to suppose that the check valves (shown in Figure 1) were not in place and the working fluid is free to flow backwards through Brayton1. A portion of

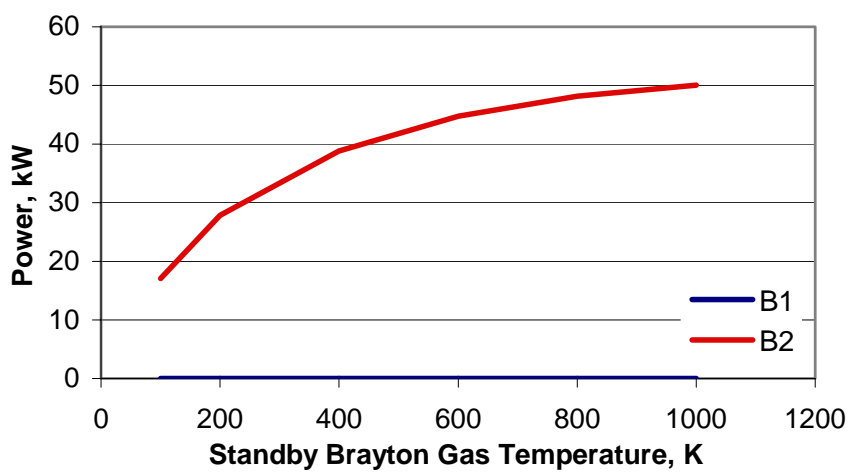

Figure 6. Brayton2 Output Power as a Function of Brayton1 Gas Temperature.

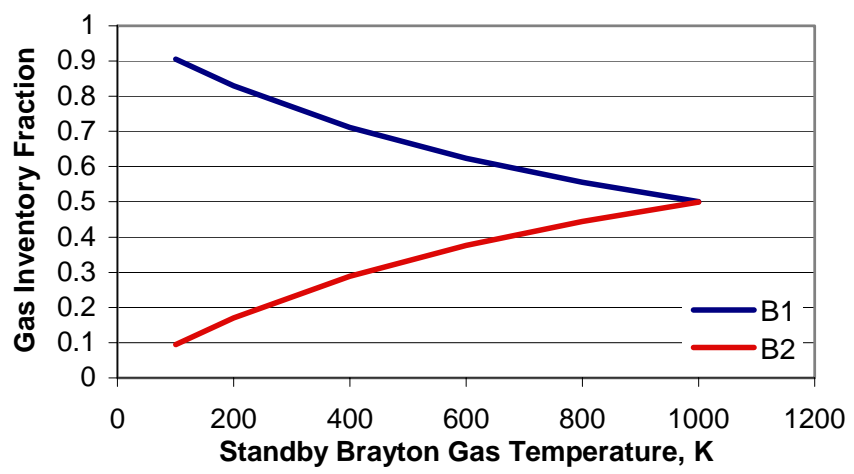

Figure 7. Brayton gas inventory as a function of Brayton1 gas temperature.

the hot gas from the Brayton2 recuperator high pressure exit (around $900 \mathrm{~K}$ in Figure 3) would circulate through Brayton1, keeping its inventory relatively warm. However, Brayton2 TIT would be lower than the $1150 \mathrm{~K}$ design point because mixing of the two gas streams would occur at the heat source exit. This option is feasible as long as the standby shaft is locked in place, either electrically or mechanically, to avoid damaging the bearings. A third option is to have check valves in place and periodically change Brayton2 shaft speed. This would briefly alter system pressure, which would circulate the gas in Brayton1 and cause some hot gas from Brayton2 to mix with the cold stagnant gas in Brayton1.

All three options are simply possibilities at this point. It may be the case that the stagnant gas cools at a very slow rate and the system experiences enough natural circulation to maintain an acceptable standby Brayton gas temperature. Further analysis and system testing are required to determine the possible issues associated with this operating scenario.

\section{Third Scenario: Estimate Motoring Power for System Startup}

The power conversion system will have to undergo at least one startup during its mission. This scenario investigates the estimated power required to motor the Brayton units during startup. Motoring power is an important issue because a power source (batteries, solar arrays, etc.) is required to start the system before the system can become power-producing. An obvious question when considering startup scenarios is whether the Braytons should be started one at a time or both simultaneously.

For the startup of one Brayton (Brayton2) while the other is standby (Brayton1), a uniform system initial temperature is assumed. Upon startup, Brayon2 is motored at $20 \mathrm{krpm}^{\ddagger}$ while Brayton1 stagnant gas remains at the assumed system initial temperature. Reactor thermal power is increased until the heat source exit temperature reaches $1150 \mathrm{~K}$. Figure 8 is a plot of power as a function of heat source exit temperature; values are positive when

\footnotetext{
‡ The speed of 20 kRPM was selected to allow a large margin for gas-foil bearing liftoff. No rotor-dynamic issues were taken into account. Break-away torque and acceleration from 0 to $20 \mathrm{krpm}$ were not considered.
} 
the system is power-producing and negative when motoring is required. Results are given for system initial temperatures of 200 and 400 $\mathrm{K}$. The power trends are nearly linear and the system power breakeven point occurs at a heat source exit temperature of $600 \mathrm{~K}$ for the $400 \mathrm{~K}$ stagnant gas temperature case and $560 \mathrm{~K}$ for the $200 \mathrm{~K}$ case. CCSS had difficulty generating data below the breakeven point, requiring extrapolation of the positive power data points. Extrapolating (dashed line in Figure 8) the 200 $\mathrm{K}$ stagnant gas temperature case down to a heat source exit temperature of $200 \mathrm{~K}$ shows that when one of the Braytons is operated at 20 $\mathrm{krpm}$, the maximum required motoring power is approximately $6 \mathrm{~kW}$. When the $400 \mathrm{~K}$ case is extrapolated down to a heat source exit temperature of $400 \mathrm{~K}$, the maximum motoring power is approximately $4 \mathrm{~kW}$.

For the simultaneous startup of both Braytons, both shaft speeds were held at 20 krpm while the heat source exit temperature was increased from $200 \mathrm{~K}$ to $1150 \mathrm{~K}$. Figure 9 is a plot of power as a function of heat source exit temperature. Brayton1 and Brayton2 power are identical, which is why the plot appears to have only one curve. The breakeven point occurs around $600 \mathrm{~K}$, as it did in Figure 8, but extrapolation suggests that $8 \mathrm{~kW}$ is required to motor each Brayton at $20 \mathrm{krpm}$ for a system at $200 \mathrm{~K}$. Thus, the total power required to motor both Braytons is approximately $16 \mathrm{~kW}$. For a system startup at $400 \mathrm{~K}$, approximately $5 \mathrm{~kW}$ of power is required to motor each Brayton, for a total of $10 \mathrm{~kW}$.

Motoring power for the simultaneous startup was more than twice that of the single Brayton startup. One explanation for this is because there is more gas in the standby Brayton than in the motored Brayton, less power is required to pump the lower density fluid. When the units are motored simultaneously, the Braytons contain equal amounts of gas. If the Braytons were not sharing a common gas inventory one would expect the single Brayton startup power to be exactly half of the simultaneous startup. Therefore, it appears as though motoring a single Brayton in a common gas system requires less power than a single Brayton in an independent gas loop configuration.

This scenario looked at a specific case of $20 \mathrm{krpm}$ and cold system temperatures of 200 and $400 \mathrm{~K}$. Results can be expected to vary with different speeds and cold system temperatures, but the motoring power for a single Brayton startup should be no more than half the total power required for a simultaneous startup. The colder system required more motoring power. Therefore, the use of strip heaters to elevate the stagnant gas temperature before startup could potentially reduce the startup power demands.

\section{Fourth Scenario: Possible System Startup Sequence}

This scenario looks at a possible system startup sequence. Several steady-state operating points were combined to create this sequence and time scales were not explored because system transients were not modeled. Results are plotted against non-linear time, which simply means that the pace of operations is yet to be determined. According to McCann, a typical staggered startup profile would take approximately $7 \mathrm{hr}^{7}$

The previous scenario revealed that motoring one Brayton requires less than half the power of motoring both Braytons simultaneously. With that in mind, the sequence outlined here brings one Brayton (Brayton2) up to design speed before starting the second Brayton (Brayton1). Figure 10 depicts the system startup sequence in five increments. Prior to startup, the entire system gas inventory is assumed to be at $200 \mathrm{~K}$. The sequence starts (indicated by label A in Figure 10) when Brayton2 is motored at $20 \mathrm{krpm}$ while Brayton1 remains off at $200 \mathrm{~K}$. 
Brayton2 is held at $20 \mathrm{krpm}$ to circulate the working fluid while the heat source temperature is increased to $1150 \mathrm{~K}$ (label B). Motoring is only required until the breakeven point is reached. After the system becomes power-producing, motoring is no longer required and the shaft speed is actively controlled to maintain a set speed.

Figure 11 is a plot of Brayton output power according to the sequence in Figure 10. At 1150 $\mathrm{K}$ and $20 \mathrm{krpm}$ Brayton2 produces $8 \mathrm{~kW}$ of power. At this point Brayton1 could be motored using the power produced by Brayton2, or Brayton2 speed could be increased to its design point of $45 \mathrm{krpm}$. Although $8 \mathrm{~kW}$ at $20 \mathrm{krpm}$ is likely sufficient power, at $45 \mathrm{krpm}$ Brayton2 would supply $28 \mathrm{~kW}$, perhaps a safer margin of available power. However, one reason it might be desirable to start Brayton1 before increasing Brayton2 speed is to diminish the thermal shock seen by the heat source from the sudden increase in mass flow rate. This particular sequence increases Brayton2 speed to $45 \mathrm{krpm}$ before starting Brayton1.

Once a heat source exit temperature of $1150 \mathrm{~K}$ is reached, Brayton2 speed is increased to 45 $\mathrm{krpm}$ at a rate slow enough for the heat source to maintain a steady $1150 \mathrm{~K}$ (label C). Brayton1 is then motored and will become power-producing almost immediately because a high temperature is already established in the heat source (label D). Figure 11 shows a jump in Brayton2 power output once Brayton1 begins to generate power. As noted earlier, the sudden increase in mass flow rate upon Brayton1 startup will likely cause a brief temperature drop in the heat source. Finally, Brayton1 speed is slowly increased until its design speed of $45 \mathrm{krpm}$ is reached (label E).

Many factors need to be taken into consideration for a system startup procedure. This study presents one possible scenario and only considers a few main factors. A transient model with appropriate system controls is necessary to further define the startup sequence.

\section{Conclusion}

The CBC-based reactor power system is a leading candidate for various nuclear electric propulsion (NEP) and surface power applications. Systems that utilize multiple Brayton converters with a common gas inventory may be pursued in order to provide power conversion redundancy, especially if gas-cooled reactors are considered. This study explored the performance and operational characteristics of a dual Brayton system with shared gas inventory. The study revealed several important system attributes associated with startup, imbalanced speed operation, and single-unit operation with idle standby. The startup power requirements can be minimized by staggering the startup of the two units and utilizing the first unit to start the second. Reducing the operating speed of one of the units causes a major reduction in system output power and results in a deleterious redistribution of working fluid. The operation of a single unit with an idle standby also results in a power reduction, which is exacerbated by the cooldown of the idle unit's gas inventory. 


\section{References}

${ }^{1}$ Mason, L.S., “A Power Conversion Concept for the Jupiter Icy Moons Orbiter,” AIAA Journal of Propulsion and Power, Vol. 20, No. 5, 2004, pp. 902-910; also NASA/TM-2003-212596, September 2003.

${ }^{2}$ Elliot, J.O., Reh, K., and MacPherson, D., "Lunar Fission Surface Power System Design and Implementation Concept," Proceedings of the Space Technology and Applications International Forum, edited by M. El-Genk, American Institute of Physics, Vol. 813, New York, 2006, pp. 942-952.

${ }^{3}$ Mason, L.S., “A Comparison of Fission Power System Options for Lunar and Mars Surface Applications,” Proceedings of the Space Technology and Applications International Forum, edited by M. El-Genk, American Institute of Physics, Vol. 813, New York, 2006, pp. 270-280; also NASA/TM-2006-214120, February, 2006.

${ }^{4}$ Ashcroft, J., and Eshelman, C., "Summary of NR Program Prometheus Efforts," Proceedings of the Space Technology and Applications International Forum, edited by M. El-Genk, American Institute of Physics, New York, 2007 (to be published).

${ }^{5}$ Ashcroft, J., Belanger, S., Burge, W., Clementoni, E., Jensen, K., Proctor, N. B., and Zemo-Fulkerson, A., "Key Factors Influencing the Decision on the Number of Brayton Units for the Prometheus Space Reactor," Proceedings of the Space Technology and Applications International Forum, edited by M. El-Genk, American Institute of Physics, New York, 2007 (to be published).

${ }^{6}$ Johnson, P.K., and Mason, L.S. "Design and Off-Design Performance of 100 kWe-Class Brayton Power Conversion Systems," Proceedings of the Space Technology and Applications International Forum, edited by M. El-Genk, American Institute of Physics, Vol. 746, New York, 2005, pp. 711-718; also NASA/TM-2005-213626, June 2005.

${ }^{7}$ McCann, L.D., "Use of RELAP5-3D for Dynamic Analysis of a Closed-Loop Brayton Cycle Coupled to a Nuclear Reactor,” Proceedings of the Space Technology and Applications International Forum, edited by M. El-Genk, American Institute of Physics, New York, 2007 (to be published).

${ }^{8}$ Lavelle, T.M., Khandelwal, S.C., and Owen, A.K., "Intermediate Fidelity Closed Brayton Cycle Power Conversion Model,” NASA/TM-2006-213993.

${ }^{9}$ Barrett, M.J., and Johnson, P.K., "Performance and Mass Modeling Subtleties in Closed-Brayton-Cycle Space Power Systems," Proceedings of the $3^{\text {rd }}$ International Energy Conversion Engineering Conference, Vol. 3, AIAA, Washington, DC, 2005, pp. 1596-1607; also NASA/TM-2005-213985, November 2005.

${ }^{10}$ Barrett, M.J., and Reid, B.M., "System Mass Variation and Entropy Generation in 100-kWe Closed-Brayton-Cycle Space Power Systems," Proceedings of the Space Technology and Applications International Forum, edited by M. El-Genk, American Institute of Physics, Vol. 699, New York, 2004, pp. 445-452; also NASA/TM-2004-212741, January, 2004.

${ }^{11}$ Johnson, P.K., and Hervol, D.S., "Experimental Validation of a Closed Brayton Cycle System Transient Simulation," Proceedings of the Space Technology and Applications International Forum, edited by M. El-Genk, American Institute of Physics, Vol. 813, New York, 2006, pp. 673-681; also NASA/CR-2006-214239, March 2006.

${ }^{12}$ Kays, W.M., and London, A.L., Compact Heat Exchangers, $2^{\text {nd }}$ ed., McGraw-Hill, New York, NY, 1964.

${ }^{13}$ Solar Dynamic Power Systems Branch, Solar Dynamic Power System for Space Station Freedom, NASA Reference Publication 1310, NASA Lewis Research Center, Cleveland, OH, 1993. 


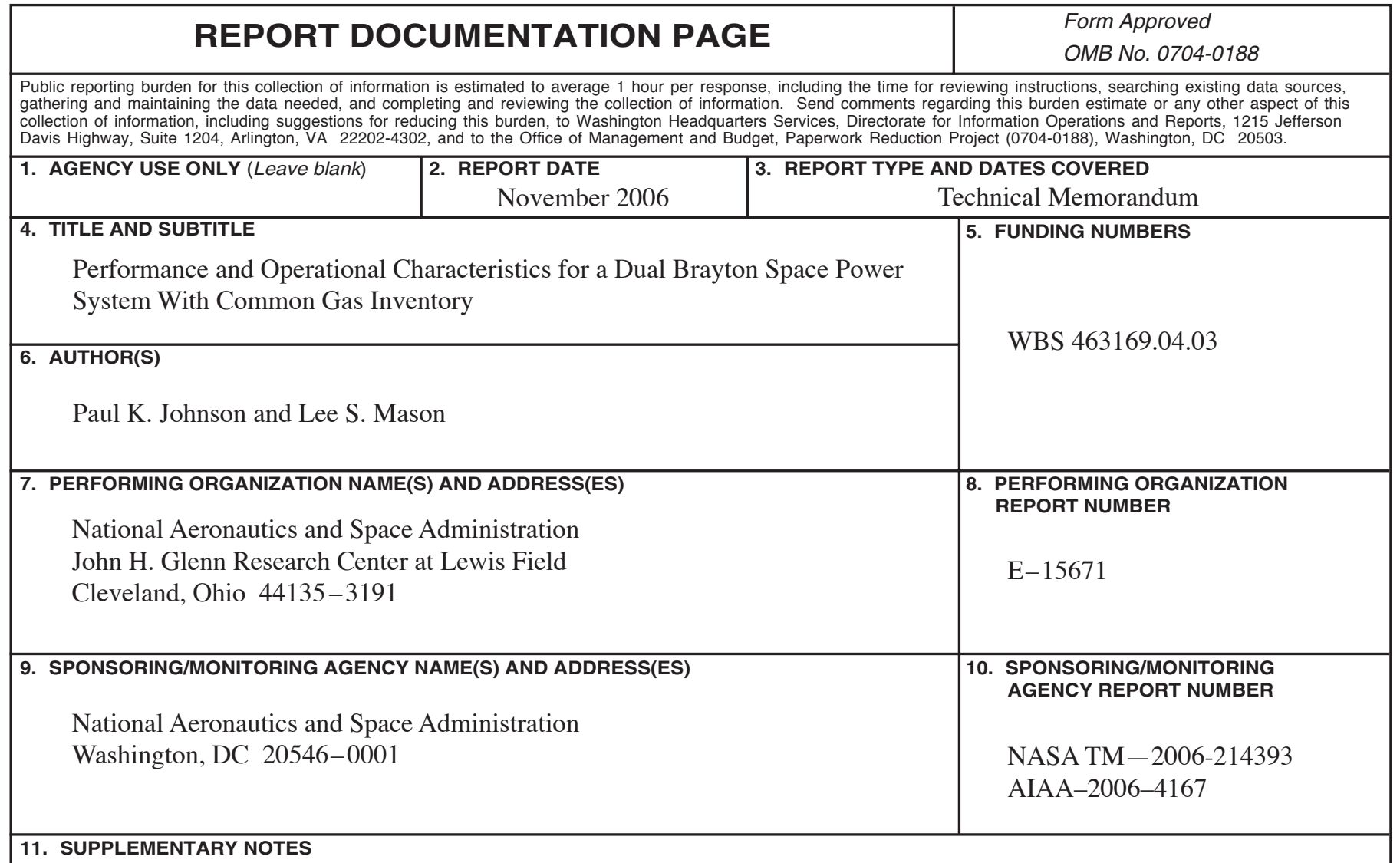

Prepared for the Fourth International Energy Conversion Engineering Conference and Exhibit (IECEC) sponsored by the American Institute of Aeronautics and Astronautics, San Diego, California, June 26-29, 2006. Paul K. Johnson, Analex Corporation, 1100 Apollo Drive, Brook Park, Ohio 44142; Lee S. Mason, NASA Glenn Research Center. Responsible person, Paul K. Johnson, organization code RPT, 216-433-3814.

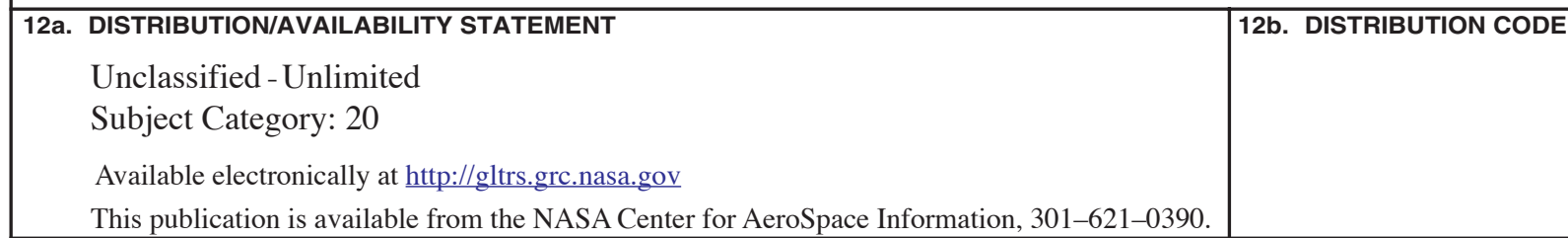

13. ABSTRACT (Maximum 200 words)

This paper provides an analytical evaluation on the operation and performance of a dual Brayton common gas system. The NASA Glenn Research Center in-house computer program Closed Cycle System Simulation (CCSS) was used to construct a model of two identical $50 \mathrm{kWe}$-class recuperated closed-Brayton-cycle (CBC) power conversion units that share a common gas inventory and single heat source. As operating conditions for each CBC change, the total gas inventory is redistributed between the two units and overall system performance is affected. Several steady-state off-design operating points were analyzed by varying turbine inlet temperature and turbo-alternator shaft rotational speed to investigate the interaction of the two units.

\begin{tabular}{|c|c|c|c|}
\hline \multicolumn{3}{|l|}{ 14. SUBJECT TERMS } & 15. NUMBER OF PAGES \\
\hline \multicolumn{3}{|c|}{ Brayton cycle; Closed cycle; Simulation } & 15 \\
\hline $\begin{array}{l}\text { 17. SECURITY CLASSIFICATION } \\
\text { OF REPORT }\end{array}$ & $\begin{array}{l}\text { 18. SECURITY CLASSIFICATION } \\
\text { OF THIS PAGE }\end{array}$ & $\begin{array}{l}\text { 19. SECURITY CLASSIFICATION } \\
\text { OF ABSTRACT }\end{array}$ & 20. LIMITATION OF ABSTRACT \\
\hline Unclassified & Unclassified & Unclassified & \\
\hline \multicolumn{3}{|l|}{ NSN 7540-01-280-5500 } & $\begin{array}{l}\text { Indard Form } 298 \text { (Rev. 2-89) } \\
\text { scribed by ANSI Std. Z39-18 } \\
-102\end{array}$ \\
\hline
\end{tabular}



